\title{
Thu Al-Ausb’a Al-'Adwani: An Arabic Poet of Acuity with Eternal Arguments
}

\author{
Yahya Saleh Hasan Dahami (Associate Professor) \\ English Department -Faculty of Science and Arts - Al Baha, Al Baha \\ University, KSA
}

Doi: 10.19044/llc.v6no1a2

URL:http://dx.doi.org/10.19044/llc.v6no1a2

\begin{abstract}
The Arabic poetry, particularly the poetry of pre-Islam age, with its valuable tradition, is one of the major influences of the Arabic world. Thu AlAusb'a Al-'Adwani is one of the great poets in the age prior to Islam. He is one of the supreme poets who brings to light erudite pictures of Arab's traditions and conventions before Islam. This paper focuses on illustrating the profundity of some verses of Thu Al-Ausb'a Al-'Adwani as a case of the prominence of the Arabic language as a result of poetry. The poet, Thu AlAusb'a, has been scarcely studied. For this reason, he and his poetry deserve to be given enough attention particularly his verse as a legacy of the graceful language.

The paper harnesses the descriptive-analytical approach. It commences with a succinct introductory outline on the Arabic language and its link with poetry. Then, in its first part, it moves ahead shedding light on the life and some events of Thu Al-Ausb'a Al-'Adwani. The next main point to be followed deals with the perceptive analysis of the poet, his wisdom, and eternal notions with reference to selected verse lines of his poetry. Through this part, the paper attempts to ascertain the importance of the Arabic language and to exemplify the capacities of Thu Al-Ausb'a Al-'Adwani through poetry. The study is concluded with a brief summary of the whole analysis and it comments on the findings if there is any.
\end{abstract}

Keywords: Arabia, Arabic language, perception, poetry, Thu Al-Ausb’a AlAdwan, verses.

\section{Introduction}

\section{Arabic Language and Poetry: Jewelry of Knowledge}

The Arabic language, with its rich literary tradition, is one of the major tongues of the domain. Since the Middle Ages, it has appreciated a universality that makes it one of the world's pronounced tongues, along with several other 
languages of the world. This status does not only reflect the number of Arabic talkers, but also it reflects the place that the language has occupied in history. In addition, it shows the significant role it has played in ancient times and, today, in the development of the Arabic and Islamic societies. The image, appearance, impression, and the aura of classical Arabic have continued to be recognized and valued in all the Arab countries. The desire for poetical writing was passionate in the Arabic language. Arabic poetry was limitless "in number and is transmitted from mouth to mouth. It was of great attraction where all listeners admired them, whether or not the people are high or low, rich or poor. Poetry in the Arabic language is full of music and exquisite accent" (Dahami, 2015). The Arabic language has not merely remained supplementary to Islam but has been important as a medium of cultural and national restoration in the Arabic-speaking nations. Arabic is the national tongue of the Arabian Peninsula, the North African states, and the Fertile Crescent.

However, it is the religious language for the Islamic countries. In the course of its progress, Arabic owing to favor from several languages has acquired a considerable amount of terminology. This has made significant influences, effects, contributions, and impacts to several Eastern and Western tongues. Moreover, Arabic has put its conspicuous mark on both terminology and script in too many countries of the world because of several factors. Three of them are The Holy Quran; the second is its famous literary and poetic language; and the third is the different civilizations all over the ages which contributed to the spread of the language through travels, commercial dealings, and relations. The Arabic language has also made the main contributions to some universal languages. In English, for instance, we found that words such as admiral, algebra, alcove, alkali, alcohol, arsenal, coffee, cipher, lemon, rice, and sugar are only a few of the many expressions found in the universal tongues which are of Arabic source or have been transferred through the standard of Arabic. This has evolved noticeably since before Islam with hundreds of years. The Arabic language is not an intruder in the new environments but contends with numerous recognized languages that possessed pronounced literary heritages.

The Arabic language has been formed beside various tribal dialects of Arabic spoken by each tribe. Its usage is simple, smooth, and comfortable and its understanding is not tricky to other heterogeneous tribes. The Arabic language is perfect and free from flaws and shortcomings. Moreso, it is the language of the literary societies, as well as the language of poetry and oratory. Dyck (1894) opines that it is one of the best languages of the universe based on two respects; first as regards to the richness of its terminology and second owing to the richness of its literature (p. 40).

Furthermore, the classical Arabic language has welded all other Arabic dialects and expressions, and has shaped one of the finest in those tongues of 
components and modules. This has gotten rid of the defects that characterized other dialects. The Arabic language has emerged the best through the Qur'an and from the literature of ancient times, its prose and poetry. This idea was supported by Gruendler (2002), when he stated that "classical Arabic poetry is the literary canon from which medieval Arab linguists, genealogists, and other scholars take evidentiary verses (shawiihid) to support their arguments. In this way, ancient poetry 'judges' many as a scholarly case" (p. 257).

Arabic poetry still retains the top rank among the list of the literary genres in the Arabic language. It did not budge an inch from its stature that it has occupied since the era of pre-Islam, approximately more than sixteen centuries. It is still the Diwan of Arabs. Thus, this means that poetry is the cultural lounge or salon of literary figures.

Several critics have believed that the reasons for the composition of the Arabic language as literary are numerous. (1) Some of them might be the conditions created by the specialists of Arabic language for their language until it reached the rank it is nowadays. (2) It is the conversational style and continuous communication with life. (3) The Arabic language seems important in Arabic society as a medium of oral poetry. (4) This poetry, been abundant and rich, not only occupied a special place in the life of the several tribes but also served as a koine and unifying force among them. (5) It is to the poetry that the Arabs owed their awareness of being one people because this gave focus to their artistic, intellectual, and spiritual expression. (6) The importance of this poetry is further attested to by the enviable position of influence which the pre-Islamic poet enjoyed among the members of his tribe and through the power of his highly rhythmical and forceful verses (Chejne, 1969, p. 8).

This is the honest and trusted carrier of information, and it is the means of life in its simplicity. Nevertheless, it is a stable origin among the prosiest and poets who presented a competing productive language by selecting clear vocabulary and smooth compositions, which the historians of ancient literature indicate: carnivals, literary and commercial activities, and religious celebrations conducted where poets and orators do meet in presenting their literary products. Souk Okath (also written as Okaz) was the most significant celebrating place where people gather in a specific season of the year. However, critics have described the situation based on the fact that to speak Arabic was and still remains a language which everyone understands its poetic meaning. The poet and the orator are careful in selecting or using elevated and high diction in a perfect and ideal language which has unison and harmony fit for all listeners. Thus, no one finds it strange. The literary festivals were conducted in several towns, communities, and villages of the Arabian Peninsula, notably Mecca, Taif, the Arabia Felix and others that had a 
particular impact in unifying Arabic tongue and circulating the ideal classical language, making it primacy among the writings of other nations.

Currently, the Islamic and Arab historians are/were chiefly, according to Faris (1946), interested in the Holy Quran, poetry, and genealogy. They have portrayed two main qualities in the history of the period before Islam: the first, the city of Mecca and its holy place of worship and pilgrimage, the Ka'bah; the second is the natural open life of the nomads (p.43). This can be seen through the setting of the thirsty but imaginative land as its scenery and with the diverse recurrence of minor invasions and fights for the proprietorship of a water source or the revenge of a killed kinsman. Thus, Мecca was a significant center in Arabia, and Bedouin life is the most typical feature of the age preceding Islam. However, those who stimulate Arab customs and make the prevailing practice of the Arabic poetic language can be seen in several cases. According to Coke (1929), "no longer Arabs themselves; few of the legalists, philosophers, historians, poets, storytellers who adorned the Court of Baghdad and made the Arabic language one of the most prolific in literature in the world could boast the blood of Arabia" (p. 77.). Browne stated that; "The Arab mind ... is clear and positive, and the Arabic language is nervous, virile, and rich both actually and potentially. The old Arabs were acute and observant people" (Thorndike, 1927, p. 285).

Tribes of Arabs used to hold a manner of dominance. This is confirmed in the significant land of Arabia particularly in the region of Mecca and Medina, as well as in Nejd or what is called "the high land of central Arabia, at the time when the earliest extant Arabic literature was produced. There is no doubt that these spoke with all the grammatical inflections. The poetry of the period is a sufficient proof" (Chenery, 1869, p. 12). Similarly, in regards to the degree of how we can speak, "Mecca made a nearer approach to the contemporary standard of civilized life than any other settlement in peninsular Arabia" (Hogarth, 1922, p. 17).

\section{Thu Al-Ausb'a: His Life and His Clan}

Instead of being a man of carnage like 'Amru ibn (son of) Kolthoum, Orwa ibn Al Ward, Tarafah ibn Al-A'bd and most of the poet-knights of preIslam age, Thu Al-Ausb'a Al-'Adwani is a wise man who is admired by his tribe. This is with exception of a few factious, whose conspiracies and hatred of bias cannot do it. Thus, this result to the emergence of his usual longsuffering, though, weakening the war-like qualities which is so highly valued and appreciated by the Arabs.

The real name of our poet is Hourthan ibn Al-Harith ibn Muhrith ibn Tha'labah ibn Saiyar ibn Rabiya'h ibn Hubairah ibn Tha'labah ibn Thareb ibn 'Amru ibn Obad ibn Yashkor ibn A'dwan ibn A'mru ibn Sa'ad ibn Gais (it is also written as Gaiys) ibn A'ilan ibn Muthar ibn Nizar of the powerful tribe of 
Adwan (Al-Asfahani, 2008, p.62). "The famous legendary Hakam, 'sage' or 'judge,' is called 'Amir son of adh-Dharib [A'amer ibn Ath-Tharb], referring to one whose tradition has a number of stories. Also, the tribe possessed the privilege of giving the ijazah or signal for dispersion to the pilgrims at the annual pilgrimage to Mecca. However, they are said to have fallen from this high estate owing to internal dissensions, their numbers being significantly reduced by intestine wars" (Al-Mufaddal, 1918, p.109). Thu Al-Ausb'a Al'Adwani was a knight who participated in many invasions and famous battles (Al-Asfahani, 2008, p.62). He is a little older than Orwa ibn Al Ward and descended from Mouthar by Gais ibn Ilan. He is nicknamed Thu Al-Ausb'a because one of his fingers had dried out been bitten by an adder. He distinguished himself by his achievements and his poems during the long cacophonies that destroyed the sovereignty that the tribe of Adwan exercised over several Arab nomadic communities.

Therefore, the power of the tribe of Adwan is attributable to several causes: the first is his high power, since this had once counted among his folks seventy thousand young people, selecting only those who are uncircumcised. Such affluence must be added to the intelligence of the tribe of the wisdom of A'amer ibn Ath-Tharb, who had been recognized as the supreme ruler and arbiter by all the Arabs who descent from Gais. When he was old, one of his sons criticized him that to want justice is disdain; then A'amer requested him to indicate to him, by a signal arranged between both of them, the errors he might do in the future when he is taken for adjudication. Subsequently, when he delivers his decisions and is mistaken, his son, outside the tent, hits a bowl with a rod, and this noise shows his slip. This is the source of the phrase which the Arabs used to assign it: the one for whom the stick is struck (لأني كانت تقرع (العصا له (As-Seuddi, 1986, pp. 20-21). It is also to A'amer that the poet AlMutalamis, the cousin of Tarafah, alluded in the following verse line: (Ibn Gutaiybah, 1982, p. لذي الحلم قبل اليوم ما تقرع العصا وما عُلّم الإنسان إلا لبعـلـــا

Previously, the rod had never been struck for the Lenient; he is only counseled so that he could recognize what is right.

This line is said by Al-Mutalamis, the uncle of Tarafah ibn Al-Abd. He meant that the intelligent man (ذو الحلم) is the wisest of his tribe A'amer ibn Ath-Tharb Al-'Adwani after being aged. His son invented a means to help the wise judge in his verdict if it is not proper. It is a sort of perspicacity that AlMutalamis indicates representing Arabs. The second hemistich ( وما عُلّم الإنسان (إلا ليعلىL is of great importance in which it bears a universal and moral message in life. It is the everlasting process of learning. There are few Arabic maxims equivalent to this line of Al-Mutalamis such as the proverb saying "طلب العلم من المهد إلى اللحد" (Murad, 2003, p.57), which means “seek knowledge from the cradle to the grave” (Clarkson, 2008, p. 143; Zachariah, 2015). The 
greatest instance referring to the situation of wisdom concerning learning and acquiring knowledge is taken from the Holy Quran: "We rise to degrees to whosoever we will, but overall those endowed with knowledge is the All-

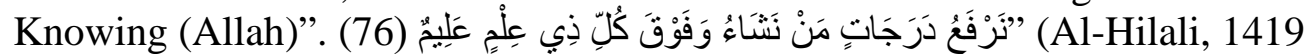
H, p. 314).

This judge bore the name, as it is mentioned above, Hakam or referee (حكم). Nevertheless, A'amer is not the only Arab who has received the name, the tribe of Rabiah, who conferred this power on Abdallah ibn Amru bin Harith, and the inhabitants of Yemen to Rabiah ibn Mokhashin nicknamed Thul 'Aouad. Thus, he is the first prince who sat on a crowned chair to judge with justice. Consequently, the dignity of Hakam is one of the bases of the early Arab societies.

The tribe of Adwan added to the causes of guidance and power over a significant part of Arabia, the religious reputation that the privilege of conferring Ijazah (permission) on pilgrims had given them when they left the town of Mecca. It is a ceremony that occurs at the end of the pilgrimage events, in which the one who was given the Ijazah came forward to see the crowd assembles at Mina (an area of Mecca in which pilgrims spend some nights worshiping Allah). Moreover, after giving him a speech, he makes a prayer for the affluence of the pilgrims, and he grants the assistants permission to depart to their clans.

Afterwards, having had so much grandeur and majesty, the tribe of Adwan fell from these honors on account of intestine wars, of which here is the reason. The branch of the Adwan descended from Naj ibn Yashkor ibn Adwan who made an incursion against the one who initiated from Yashkor ibn Sa'ad ibn Ath-Tharb. As Bano Auf (Bano, also written as Banu or bani; it is the plural of ibn which means 'son of') stood on their guard, Bano Naj could not surprise them. The result is a clash in which Bano Naj killed eight men, among whom is Omair ibn Malek, chief of Bano Auf. Nevertheless, they killed only a warrior of the aggressors, Sinan ibn Jaber, the chief of Bano Wathilah, Wathilah is Ath-Tharb's brother who had united with Bano Naj in the hope of obtaining some treasures through looting. Bano Auf consented to receive the blood money to end the conflict, and fight between the two clans of the same tribe, but Mareer ibn Jabir refused to receive a ransom from his brother, whom he determined on to take vengeance. As a result, the big robust and powerful tribe of Adwan splited, and the clans fought against each other for years until they were smashed and weak. The glory vanished.

Thus the incidents about the story is that our poet, Thu Al-Ausb'a Al'Adwani, is then sent to Bano Naj for peace. He pointed out to Mareer and his people that Bano Auf had lost eight men, and had however accepted to be compensated with blood money. Also, impartiality had it that they, who had 
lost only one warrior, did not display themselves more demanding than their brethren. On the other hand, the clan of Bano Naj remained inflexible.

\section{The Poet of Perception with Eternal Words: Analysis and Discussion}

The reason for the division of the tribe of Adwan, which led to fighting each other until they were almost demolished and shattered, was because Bano Naj ibn Yashkor ibn Adwan invaded Bano Auf ibn Sa'ad ibn Ath-Tharb ibn Amru ibn Abad ibn Yashkor ibn Adwan. Bano Auf warned both branches of the tribe which joined the severe first fighting that resulted in killing eight from Bano Auf by Bano Naj. Among them is Omair ibn Malik, who is the leader of Bano Auf. Moreover, Bano Auf killed a man of Bano Naj who was called Sinan ibn Jabir. They were detached by war and are threatening each other about an upcoming war. The one killed of Bano Naj was the leader of Bano Wathelah ibn 'Amru ibn Obad ('Awaid, 2017, p. 136; Al-Asfahani, 2008, p. 63).

There was an attempt of reconciliation by paying blood money as compensation. However, Mareer ibn Jaber refused to accept the blood money for Sinan ibn Jaber. Mareer and several of his clan and tribe separated from the other gathering who are satisfied with peace by paying compensation blood money. Thu Al-Ausb'a Al-'Adwani, as peacemaker, went to Mareer and his group urging them to accept the payment and telling them that the loss from Bano Naj is only one man and the loss of the other side, Bano Auf, are eight, and they accepted compensation for peace. However, they rejected the peace and the compensation offer. For this, it was the flame of severe continuous wars until the two clans of the tribe were about to be demolished. Thu Al-Ausb'a Al-'Adwani, for such an event, versified the following regretful lines. It is to these events that Thu Al-Ausb'a alluded to in the following verses:

(Thu Al-Ausb’a, 1973, ويا بؤس للأيام و الدهر هالكا وصرف الليالي يختلفن كذلكـا

Misery to you who do not realize perishability; exterminating cruelty of fate and times such are the fluctuations of fortune.

In the above line, with an acuity illustration, the poet presents a regretful and disdained picture of the downfall of the great tribe of Adwan. After the tribe was a leading one among Arabs, it is degraded, ruined, tarnished, lowered, and perished by stoutness, obstinacy, and stubbornness by people stated by Mareer ibn Jaber. Having people of stout and stubborn minds are the flames of catastrophe and upheaval against their clans. Our poet argumentatively addresses vain people through time and days saying that "miserable people do not realize the eternal reality of life." Life is changing, and events are changing like day and night. He acutely brings a real and touchable calamity in all ages even today. Thu Al-Ausb'a, through his talented 
way of using Arabic, presents, in this line and those to follow, a chain of connected consequences that resulted in his tribe perishing. The perishing chain according to the verse of the poet commences from pigheadedness which leads to anger and unwise challenge. A foolish challenge in this regard leads to encounter and fight. No doubt that fighting leads to killing and killing leads to perishability.

$$
\begin{aligned}
& \text { فلا تتبعن عينيك ما كان هالكا (p. 69) } \\
& \text { أبعد بني ناج وسعيك فيهم }
\end{aligned}
$$

Do not bother yourself after the murders of Bano Naj and the attacks against the outfits; the eyes will not meet the dead.

The poet in the line above continues his argument and contemplation on his tribe, Bani Adwan, advising his listeners not to open the way for the eyes remembering the past and comparing it with the devastating present. This is because of the stubbornness of Bano Naj and his failure endeavor in settlement and making peace.

$$
\text { إذا قلت معروفاً لأصلح بينهم يقول مرير لا أحساول ذلكـا (p.69) }
$$

I try to say a few words of peace to restore harmony between them, Mareer replies: do not try.

Therefore, the main point here is about the conflict that took place among the clans of Adwan tribe. He made a peace endeavor with Mareer as a word of favor and indulgence for the benefit of the whole tribe, but the reaction of Mareer is harmful, responding not to try.

$$
\text { فأضحوا كظهر العود جب سنامه تحوم عليه الطير أحدب باركا (p. 70) }
$$

Mareer's clan, viler than a camel to which the hump has been cut, Mareer dragging himself toward his enemies, bowed, kneeling.

The poet depicts weakness of Bano Naj after refusing peace among the clans of the tribe to the degree that outsiders took it as a chance that other people are greedy with them. He depicts them as weak, bowing and kneeling as a way of being small subjects. This is the power that people of pre-Islam were in need to possess. Possessing power to them means owning the life; so they were always searching for ways to seize it. The coherent tribal system that people used to provide excellent protection to individuals is one of such ways. Weaknesses for such people means death; it makes the seekers of living and its sources of livelihood covet over them, hovering around them as a bird hovers around corpses or fatigued and parking camel.

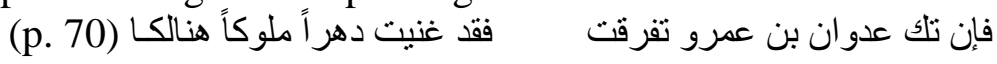

If the Adwanites, son of 'Amru, disperse, they have long been Kings there for long.

The majority of the poems of our poet deals with deploring on the greatness of the tribe of Adwan, but the above line takes a deviation from the 
nature of the poet. The line presents a clear argumentation and a beautiful picture on his tribe saying that even now, the tribe of Adwan is weak and scattered however, it has once ranked first among the tribes of Arabia. Its people were brave; thus wise kings led all strong warriors and poets. It is in the wars that followed that Thu Al-Ausb'a Al-'Adwani acquired his fame as a warrior and a poet. He employed his aptitude particularly in deploring the destruction of his tribe. It is this type in which he outrivaled for most of the fragments that his poetry has preserved. Most of his poems are in the elegiac type.

$$
\text { يا عمرو إلا تدع شتمي ومنقصني أضربك حيث تقول الهامة اسقوني (p. 92) }
$$

O Amru, if you do not stop wounding and degrading me, I will wallop you that the owl continues saying 'let me drink.'

Moving to another part of the Diwan of Thu Al-Ausb'a, we find his attack on his cousin of the other branch of the tribe, showing his boasting of himself and ascending his value over his cousin who became an enemy. The poet threatens his enemy even if he is one of his kin. He addresses his cousin with a sort of threat saying that if you do not stop insulting me, I will show you in action not only by words. I will hit you with my sword in your head. The verse line above refers to the belief that the soul flew after death in a shape of an owl, and stayed at the bottom of the tomb of the one who had been murdered, shouting ceaselessly: Give me drink.

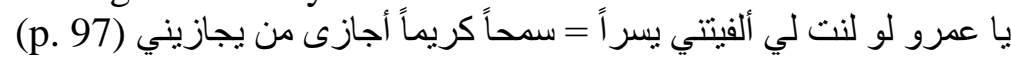

O Amru! If you show flexibility toward me, you will find me tolerant and generous, it is the way that I reward the one who gives me respect.

In other words, the poet shows his kindness, easiness, and generosity but with pride. Thu Al-Ausb'a again forwards his speech to his cousin Amru, but now the poet gives a beautiful and positive image. He argues with him saying that "if you came to me with an amenable, agreeable or responsive manner, you would find me more than what you expect”. With easiness I am open-hearted. Tolerance, generosity, hospitality and leniency are my qualities. This line is a reaction to the previous one to confirm the talent of Thu AlAusb'a presenting his real personality for which the first line does not represent his character except when there is an aggressive or insulting treatment from others. These exclusive two lines are not only representing Thu Al-Ausb'a Al'Adwani, but also they are the manner of Arabs in general, ancient and in contemporary time.

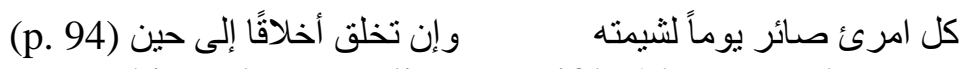

Everyone returns to his real personality, even if he/she pretends a new character for a while.

One of the striking lines full of wisdom in the poetry of Thu Al-Ausb'a Al-'Adwani is the above one. It is indeed a verse line, but its meaning can be 
penned in pages. The wise poet, as it is mentioned earlier, lived for a long time. There are sources like (Al-Alosi Al-Baghdadi, 2009, p. 329; AbdurRahman, 2015, p. 100) that Abo Hatem As-Sjestai mentions that he lived almost three hundred years, but according to what has been mentioned in his Diwan, Thu Al-Ausb'a approximately lived one hundred and seventy years (Thu Al-Ausb'a,1973, p. 12). Truly, a person who lived such a vast life is full of experience and knowledge gained from the universal life school. This longliving man produced many amazing lines like the above and several others which deals with what people need to realize in this contemporary age. The poet says that everyone, morally speaking, has his/her morals and behaviors that cannot be changed smoothly; even if they try to conceal or change their morals, they cannot. This shows that a person can pretend to change the behaviors for a while but, according to the poet, will never maintain the changes forever. A time will come that such a person might be fed up with pretense, returning to his nature, especially if this nature is uneven. If a person, for any purpose, assumes a borrowed personality for days, months or even years, he returns to his normal personality. This line of Thu Al-Ausb'a reminds us of the verse line of Zohayr ibn Abi Solma Al Muzni. The two lines of these two ancient poets go parallel in meaning but of different phrasing.

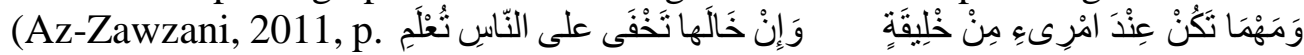

Whatever bad habit a person has, it would be in vain trying to hide it from people.

One of the most vital points Zohayr shows in the above line is morality or morals. The morals or habits of their people measure societies. They are noble motives. The poet, here, sheds light on the habits of people and how they should present themselves openly and frankly without any deceit or mischief. Zohayr says that the habits and behaviors of people are discovered even if it is late. Furthermore, Zohayr adds:

Wisdom is a very distinct trait of the poet Zohayr ibn Abi Solma. It is said that he is the wisest poet of Mua'llagats' poets. His wisdom prevented him from being attracted or drawn to war and battles. On the contrary, he stood firmly against the voices that urged him to use his talent and intellect for war as it was the nature of many distinguished poets of the period preceding Islam. Here is a verse that delineates wisdom in a clear and bright wasf (description).

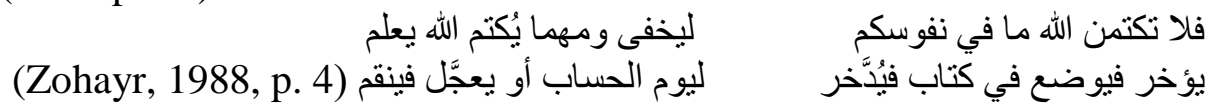

Do not hide from Allah what is in your chest that it may be concealed; whatever is concealed, Allah knows all.

If delayed, it is recorded in a book, so that it is postponed to the day of hereafter or to hasten revenge. 
Zohayr lived a very long life with prosperity. He gained great wealth from his skilled craft of saying amazing imaginative poetry given to him from the leaders and honorable men of his tribe. The above two verse lines indicate that he was a Unitarian and a believer of the hereafter. Zohayr advises his people to be honest, sincere, and truthful. According to the poet, good people are those who do not conceal and hide something from others in their hearts. Such doing is the habit of devilish creatures. Any immoral action that is made secret or hid will be revealed. In all cases, if a person planned inside his mind to do a dangerous hidden task, it shall not be concealed from Allah (God) Who knows everything whatever it is. Such an idea is supported by verses of the Holy Quran in different Surat (Chapters) of the Quran.

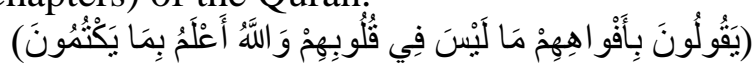

"Saying with their mouths what was not in their hearts. Moreover, Allah has full knowledge of what they conceal" (Al-Hilali, 1419 A. H. p. 100, verse167).

The second line supports the first but with broader elucidation to the power of Allah even if it is delayed or postponed. Sapiential advice says "do not hide a secret from Allah; God knows your secret; He knows all that is hidden." The wise notion understood here is that 'suppose the devilish action or intention is successfully concealed in this life, it is just delayed to the eternal day of interrogation (a symbolic connotative expression means the day of hereafter). The poet believes that such action(s) is/are recorded in a book. The recording book is saved, kept, and protected by the Omnipotent Allah for that day. It is also true that the doer(s) of such action(s) is/are punished hurriedly as reaction revenge to their ill intention.

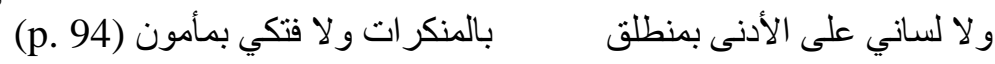

My tongue never unleashes against the esteemed one; however, my mouth is aggressive against those impetuous.

The poet, in this line, shows his high morals in dealing with others. His logic is elevated in which he never assaults those who are ranked below him as a sort of dignity. However, his attack is like the lion in the needed time. The Arabic expression al-adna (الأننى) has more than one meaning. It might also mean the one who is close or near to the speaker. So, here we have more than one possibility for the same word. The tongue of our poet does not articulate malevolence and meanness. Thu Al-Ausb'a Al-'Adwani is an epitome signifying his age and his nation.

\section{Conclusion}

The Arabic language is staged as the fulfillment and superiority of phraseology and it is broad with flashes of wit and pageantry. Commonly, the poems of Thu Al-Ausb'a might be estimated as one of the heroic quantities of the literature of Arabic tradition and institution because it involves Arabic birthright and culture. The poetry of Thu Al-Ausb'a had been brought to light 
as a work of outstanding ability. Thu Al-Ausb'a Al-'Adwani could fashion intelligence of striking attitudes and provoke the tautness of appealing elements and fundamentals.

The poetry of Thu Al-Ausb'a, evidently, included powerful and influential responses considered by the superiority of self-assurance. Undoubtedly, the poetic imageries emphasizing the abilities in people are fashioned and have compassionately received unlimited circles. This investigative sudy was carried out to consider the symbolic and engaging portraits in Thu Al-Ausb'a Al-'Adwani; as a poet of acuity and perception. The study estimated at scrutinizing and inspecting the symbolic and rhetorical images in some verses of Thu Al-Ausb'a Al-'Adwani. It tried to pursue the rational manner and mode placed on the most significant topic for recording the evolvement of the study, presenting and evaluating greatness of the used poetic language. In addition, it also tried to investigate the acuity and perception of the poet. Thu Al-Ausb'a Al-'Adwani expresses an epitome of fundamental Arab maxims and ethics in the pre-Islamic era. It is hoped that the paper reached specific interests about the influence of Arabic poetic language and its inspiration on the life of people through raising standards and adjusting their conducts.

The fragments of the poetry of Thu Al-Ausb'a depicted the stand against stoutness, obstinacy, and stubbornness of some arrogant members of his tribe, which led to the degrading and weakness of the eminent tribe of Bani Adwan. This attempt possibly will want more studies to thoroughly reach the objective of penetrating the perspicacity and wisdom of a poet-philosopher like Thu Al-Ausb'a Al-'Adwani. What has been expressed in this brief analysis might not be enough to fully accomplish the objective of probing the density of a work like the poems of Thu Al-Ausb'a Al-'Adwani. Hence, it is worthy of further investigations.

\section{References:}

\section{Arabic}

1. Abdur-Rahman, N. A. (2015). Tarikh Al Arab Gabl Al-Islam (History of Arab before Islam) $1^{\text {st }}$ Ed. Aljanadria for Publishing and Distribution.

2. Al-Alosi Al-Baghdadi \& Mahmoud Shokri (2009). Bulogh Al Erab fi Maraifat Ahwal Al Arab Part 1(Editor: Mohammad Bahjat Al Athari). Beirut: Dar Al Kotob Al Ilmiyah.

3. Al-Asfahani, A. (2008). Kitab Al-Aghani, Vol. (3) $3^{\text {rd }}$ Ed. Beirut: Dar Sader Publishers.

4. As-Seuddi \& Jalaluddin AbdurRahman (1986). Al-Wasael fi Musamarat Al-Awael (The Manners in the Sedentary with The Wise Ancients). Beirut: Dar Al Kotob Al Ilmiyah. 
5. Awaid, A. A. (2017). The Call to Peace from Pre-Islamic Poetry: A Study in Themes and Characteristics. Amman: Academic Book Center.

6. Az-Zawzani \& Abo Abdullah Al Husien ibn Ahmad (2011). AlMua'llaqat As-Saba', (the Seven Hanging Poems of Arabs) Beirut: Dar El-Ma'refah.

7. Ibn Gutaiybah, A. M. Ash-Shi'r wa Ash-Shua'ra (Poetry and Poets) Vol. 1. Cairo: Dar Al Ma'arif. 1982.

8. Murad, Y. H. A. (2003). Morals of the Teacher and the Learner for Muslim Thinkers from the Mid of Second Century of Hijra to the End of the Seventh Century. Beirut: Dar Al Kotob Al Ilmiyah.

9. Thu Al-Ausb'a \& Al-'Adwani (1973). Diwan Thu Al-Ausb'a, Al'Adwani: Hourthan ibn Muhrith (collected and verified by Abdulwahab Mohammad Al Adwan and Mohammad Na'ef AdDulimi). Al Mosul: Matba'at Al Jomhor.

10. Zohayr ibn Abi Solma (1988). Diwan Zohayr ibn Abi Solma, (with an introduction and interpretation by Ali Hasan Fa'our). Beirut: Dar Al Kutub Al-Elmiah.

\section{English}

11. Al-Hilali, M. T \& Khan, M. M. The Noble Qur'an: English Translation of the Meanings and Commentary. Madinah: King Fahd Complex for the Printing of the Holy Qur'an. $1419 \mathrm{H}$.

12. Al-Mufaddal, M. (1918). The Mufaddaliyat: An Anthology of Ancient Arabian Odes. Lyall, Charles James (ed). Oxford: At the Clarendon Press.

13. Chejne \& Anwar (1969). Arabic Language: Its Role in History. Minneapolis: University of Minnesota Press, Accessed December 8, 2018 from ProQuest Ebook Central

14. Chenery, T. (1869). The Arabic Language: A Lecture. London: Macmillan and Co.

15. Clarkson, P., Presmeg \& Norma C. (2008). Critical Issues in Mathematics Education: Major Contributions of Alan Bishop. NY: Springer Science \& Business Media.

16. Coke, R. (1929). The Arab's Place in the Sun. London: Thornton Butterworth Ltd.

17. Dahami, Y. S. H. (2015). The Contribution of Arab Muslims to the Provencal Lyrical Poetry: The Troubadours in the Twelfth Century, Journal of Arts, Vol. 27, Number (1), King Saud Univ., Riyadh. pp. 119.

18. Dyck, E. A. (1894). History of the Arabs and their Literature: Before and After the Rise of Islam. Ig. V. Kleinmayr \& Fed. Bamberg in Laibach. 
19. Faris, N. A. (1946). The Arab Heritage. New Jersey: Princeton University Press at Princeton.

20. Gruendler, B. (2002). Medieval Arabic Praise Poetry: Ibn Al-Rumi and the Patron's Redemption. Routledge.

21. Hogarth, D. G. (1922). Arabia, Oxford: At The Clarendon Press.

22. Thorndike, L. (1927). A Short History of Civilization. London: John Murray, Albemarle Street, W.

23. Zachariah, M. Wells (2015). Ignorance is not Bliss: Seek Knowledge from the Cradle to the Grave. Xlibris Corporation ISBN eBook 978-15035-68266 